\title{
Spray Dosage Form
}

National Cancer Institute

\section{Source}

National Cancer Institute. Spray Dosage Form. NCI Thesaurus. Code C42989.

A solution or suspension composed of active and/or inert ing redient(s) in oil or water, typically dispensed from an atomizer or nebulizer. 